\title{
How psychological well-being of adolescent based on demography indicators?
}

\author{
Afdal Afdal ${ }^{1}$, Asmidir Ilyas ${ }^{2}$ \\ ${ }^{12}$ Universitas Negeri Padang
}

\section{Article Info}

Article history:

Received Sep $10^{\text {th }}, 2020$

Revised Sep $29^{\text {th }}, 2020$

Accepted Sep $29^{\text {th }}, 2020$

\section{Keyword:}

Psychological well-being

Adolescent

Domestic violance

Demography

Perspective

\begin{abstract}
This study aims to analyze the psychological well-being of adolescents who live with the parents of victims of domestic violence in terms of the demographic aspects of the respondents. Sampling using purposive sampling technique using certain criteria. The number of samples is 42 people (23 women and 19 men). Each sample has different demographic characteristics. The instrument used was the Psychological Well-Being Scale (PWBS) on Indonesian Version. Data analysis used Statistical Product and Service Solutions (SPSS) with descriptive techniques. The research results found that: 1) the psychological well-being score of male adolescents was lower than the psychological well-being score of female adolescents; 2) the psychological wellbeing scores of the Minang ethnic adolescents were higher than the psychological well-being scores of adolescents from other tribes; and 3) the psychological well-being score of adolescents with the educational background of S1 parents is higher than adolescents with other educational backgrounds.
\end{abstract}

(C) 2020 The Authors. Published by IICET.

This is an open access article under the CC BY-NC-SA license

(https://creativecommons.org/licenses/by-nc-sa/4.0

\section{Corresponding Author:}

Afdal Afdal,

Universitas Negeri Padang

Email: afdal@konselor.org

\section{Introduction}

Family is a social system to meet the needs among its members (Kathryn \& David, 2011). However, the current phenomenon within the field has not yet been achieved so that family functions as a social system do not work. The family becomes an unsafe place and causes psychological pressure and even becomes a dangerous group for individuals. This condition is felt by all family members of victims of domestic violence, both their wives and children.

The phenomenon that often occurs is the discovery of cases of violence, especially in the household (domestic violence), among others, carried out against his wife (woman) and children (Anjani, 2016; Borneo, 2016; Merung, 2016). Children who live with parents of victims of domestic violence have problems in their psychological well-being (Victor, Grogan-Kaylor, Ryan, Perron, \& Gilbert, 2018). Children who are raised in a family environment that experience domestic violence have the potential to experience emotional or neurotic disorders (Willis, 2009).

The results also explain that domestic violence is closely related to the decline in child welfare (Brian, 2015). The research findings also explain that children who live with parents who do or victims of domestic violence indirectly experience psychological trauma (Mardiyati, 2015) for example, seeing his 
parents quarreling, parents being beaten using a dangerous tool, parents slapping each other. Children who experience trauma has the potential to grow and develop as children who are depressed and have the great potential in committing suicide (A. A. A. Hidayat, 2007).

Domestic violence also affects the condition of psychological well-being (Pattiradjawane, Wijono, \& Engel, 2019; Prihantini, 2018; Rusyidi \& Raharjo, 2018). Domestic violence that occurs within the family indirectly affects the psychological family members in it. One who gets the impact on domestic violence is children and adolescents. Often the stressors experienced by children and adolescents come from families (Perkins, Wood, Varjas, \& Vanegas, 2016) a result of unhealthy parenting.

Based on the phenomena and data above, the phenomenon of domestic violence is a very alarming issue and impacts the psychological and mental condition of children. Family life should be good for the husband, wife; children and grandchild is a port of feeling in which there are peace, longing, renewal, enthusiasm and sacrifice (Achmad, 2005). Meanwhile, the phenomenon that occurs in the field is that in the family environment, there is a lot of domestic violence that results in psychological well-being of children (Margaretha \& Rachim, 2013; Nayana, 2013) who were living with parents who are victims of domestic violence.

One factor that influences psychological well-being of adolescents is family factors where unhealthy parental relationships will cause children to have high anxiety and feelings of depression and juvenile delinquency behavior (Lian \& Yusooff, 2009). Psychological well-being is also related to ethnic/ racial individuals (Bucchianeri et al., 2016). In terms of culture, psychological well-being for Western cultural people refers to the achievement of personal goals, independent, independent, which can be interpreted as achieving actualization of self-actualization, while for Eastern cultures prosperous psychologically refers to the development of interpersonal relationships and good social relations to the environment (Fava \& Ruini, 2014). Ryff also mentioned that psychological well-being is influenced by gender, age and personality (Misero \& Hawadi, 2012).

As for adolescence, personal growth and goals in life have the highest scores from the six dimensions of psychological well-being and also emphasized that maintaining good psychological well-being when there are problematic conditions is very important for individuals (Hidalgo et al., 2010). The condition of individual psychological well-being is identified through its aspects, namely self-acceptance, autonomy, environmental mastery, life goals, personal growth and positive relationships with others (Berzonsky \& Cieciuch, 2016). The condition of domestic violence has a negative impact of the behavior of children with mothers and has an early impact and is associated with mental health (Levendosky, Huth-Bocks, Shapiro, \& Semel, 2003). The impact on domestic violence has a significant relationship to male compared to female (Evans, Davies, \& DiLillo, 2008). Children who experience domestic violence make these children isolated (difficult to socialize), confined, and can inhibit the resilience and resilience of children (Katz, 2016).

Based on the phenomena and data above, it can be seen that the phenomenon of domestic violence is a very alarming issue and impacts the psychological and mental condition of children. As explained in the Ministry of Women's Empowerment and Child Protection Regulation, there are three strategic issues on child protection, namely: 1) improving the quality of life and growth of children; 2) increasing child protection from violence, exploitation, neglect and other mistreatment; and 3) institutional capacity building for fulfillment rights and protection of children. These three issues implicitly imply the importance of these issues to be of concern, especially the first point is closely related to psychological well-being. This requires collaboration from various parties, especially the ministries of education and culture, social ministries and other ministries. So that the handling of victims of domestic violence can be done with movement and steps together. One contribution to the education sector is through implementing guidance and counseling services for adolescents who are victims of domestic violence. Therefore, it is very important to know the psychological well-being conditions of adolescents, especially teenagers are still in school. This is because often parenting unhealthy that occurs at home affect's student motivation and learning outcomes. So that through this article we will describe the description of psychological well-being of youth based on each of their demographics.

The family is a social system (Carter, 2017) comprising a mother, father and children (Bell \& Bennett, 2017; Minkus, Liu, \& Ross) sharing love, protecting each other to achieve happiness. As for achieving these goals, family functions must work. The function of the family to meet the needs of its members, including security and safety; economic and material well-being; psychological, physical and emotional well-being; and spiritual needs (Kathryn \& David, 2011). 
However, much happens in an environment where family functions are not functioning, for example, economic functions are not running so that family members experience economic difficulties (Sanders, 2015), biological functions are not running so that such things become rampant infidelity in the family and other problems (Bodden \& Deković, 2016; Foshee et al., 2016). As for the problems are likely to arise due to non-functioning of the family, namely domestic violence.

Violence is all forms of attitudes and behavior towards women both physically (Dibble \& Straus, 2017; Jonsson, Bladh, Priebe, \& Svedin, 2015; Lansford et al., 2015; Straus, 2017), psychologically (Niolon et al., 2015; Winstok \& Sowan-Basheer, 2015), sexually (Kidman \& Palermo, 2016; Sutherland, Fantasia, \& Hutchinson, 2016; Zembe, Townsend, Thorson, Silberschmidt, \& Ekstrom, 2015) and economic violence that results in the wife feeling physically hurt, depressed, anxious, helpless and so on. UNICEF also defines domestic violence as a pattern of attacking behavior and coercive behavior towards physical, sexual, psychological, and economic pressures committed by adults or teenagers (Unicef, 2006).

The impact of domestic violence includes physical (Bosch, Weaver, Arnold, \& Clark, 2017), psychological (Rivas et al., 2016), social (Maguire-Jack \& Showalter, 2016) and economic (Hughes, Bolis, Fries, \& Finigan, 2015) impacts (Stanko, 2017). The experience of witnessing domestic violence is an important factor that has intimate relationships in the adult life of witnessing. Male who grow up in domestic violence have a threefold risk of becoming perpetrators of violence against their wives and families and in adulthood. Female who witness domestic violence will grow into women who are passive, and at high risk will be victims of domestic violence to their families later (Mardiyati, 2015).

The form of reaction from acts of violence observed and experienced by children aged 13-18 years is self-destruction which is interpreted to overcome anger and depression, conduct risky behavior, take drugs, take antisocial actions, withdraw from the environment to isolate oneself, a change in personality, and experience psychosomatic.

Psychological well-being is the full achievement of one's psychological potential and a condition in which an individual can accept his strengths and weaknesses based on six aspects of biological needs that represent criteria for positive psychological functions, namely autonomy, personal growth, environmental mastery, purpose in life, positive relations with other, and self-acceptance (López-Torres Hidalgo et al., 2010; Ryff, 1984; Ryff \& Singer, 2008).

Psychological well-being of adolescents can be interpreted that an evaluation of adolescents on their lives and can receive both positive and negative sides, so they have life satisfaction and happiness. In adolescence, personal growth and purpose in life have the highest score of the six dimensions of psychological well-being, and it is also emphasized that maintaining good psychological well-being when there are problematic conditions is very important for individuals (Hidalgo, et al., 2010).

The term psychological well-being is used throughout all health sciences as a kind of accumulation of all life experiences which means the satisfaction to the heart, satisfaction with all life experiences, selfactualization, feelings have achieved something that is desired in the form of peace of life and happiness (Sharma \& Sahu, 2014). Well-being is a dynamic concept that includes subjectivity, social and psychological dimensions (Taylor, 2011) and health-related behaviors. Individuals with high psychological well-being can be said as individuals who have feelings of satisfaction and happiness in their lives (Pinto, Fumincelli, Mazzo, Caldeira, \& Martins, 2017).

We can know that if there are problems in adolescents, they can affect the purpose of life and personal growth of adolescent psychological well-being and become an important part of an individual's life. Adolescence is very important in improving well-being, as explained by Garbarrino, ecological system theory studies that the well-being of children and adolescents is influenced by their environment such as relationships with parents, peers, teachers and significant others both in the school environment and community environment (Tartakovsky, 2010).

Psychological well-being develops from early adolescence through young adulthood, where adolescents who have friendship networks in class affect their academic achievement and psychological well-being of these students (Yi, 2012). Based on the explanation above, it can be concluded that at the age of adolescence, adolescents should have high psychological well-being important in the personal growth of adolescents, life goals and academic achievement in school.

Problems in the family become a very worrying issue, especially among the community (Afdal, 2015). The phenomenon that is rife is the discovery of cases of domestic violence committed against a wife 
(woman) and her children (Merung, 2016). The phenomenon of domestic violence for victims, especially family members, has a profound impact both physically and psychologically (Afdal, 2015). It relates one risk of concern to the psychological well-being of children living with domestic violence parents. The impact of domestic violence on children both physically and psychologically include: children experiencing injuries, bruises, bumps, the embarrassment to meet others, alienating themselves from the family environment, and loosening of the relationship between the perpetrators of violence with children who are victims of violence (Anggraeni, 2013). In addition, children who live with the victims of domestic violence have problems in their psychological well-being (Victor, et al., 2018) or the child has an unhappy psychological condition. Domestic violence causes not only psychological well-being bad for adolescents. It can even cause PTSD (Post-Traumatic Stress Disorder), anxiety, depression, aggression and delinquency (Callahan, Tolman, \& Saunders, 2003). Based on the above phenomena and data, it can be seen that the phenomenon of domestic violence (domestic violence) is a very worrying issue and impacts the psychological and mental condition of children and adolescents living with parents of victims of domestic violence. Therefore, this research intends to to analyze the psychological well-being of adolescents who live with the parents of victims of domestic violence.

\section{Method}

This study uses a quantitative approach which analys the psychological condition of adolescents who live with the parents of victims of domestic violence in terms of demographic aspects of the respondents. Sampling using purposive sampling technique using certain criteria, including: 1) often see parents quarreling at home; 2) often hear parents say harsh words during a fight; 3 ) often see the mother cries after hearing her father utter harsh words during an argument; (4) feeling depressed when their parents argue; (5) sad if the parents do not get along; (6) shame on neighbors when parents argue; (7) jealous of family / neighbors who live happily; (8) feels sad if it causes the dispute itself and (9) has been reprimanded by his father for interfering in his parents' problems. The above criteria are detailed in the form of an initial data questionnaire. The procedure used in this study is to select adolescents who experience the impact of violence and live with the parents of victims of domestic violence. Based on initial questionnaire data, found a sample of 42 people (23 women and 19 men) aged 15-18 years. Researchers using the psychological well-being theory by Carol D, Ryff to developed this research instrument. The instrument used was the Indonesian Version of the Psychological Well-Being Scale (PWBS). The instrument has been tested for validity and reliability using the Rasch Model, which amounts to 42 items. After testing with the Rasch model, the reliability of items was 0.87 and the reliability of people was 0.89 . Each sample has different demographic characteristics. Data analysis used Statistical Product and Service Solutions (SPSS) software analysis with descriptive techniques and comparative analysis.

\section{Result and Discussion}

\section{Descriptive statistics psychological well-being of respondent}

From this aspect, respondents may have a high psychological well-being. This can be seen from the results of data analysis on each aspect, among others: the autonomy aspect has the highest percentage compared to other aspects that is equal to $80 \%$. Furthermore, the aspect of environmental mastery is $79.8 \%$, the aspect of personal growth is $79.6 \%$, the aspect of self-acceptance is $78.5 \%$, Then, the positive relationship aspect with other people is $77.5 \%$ and purposes in life is $75.6 \%$. The conclusion of the research results from the psychological well-being variable is that the respondent has good autonomy and the aspect of the respondent's purpose in life must be improved. These results indicate that in general the psychological well-being of respondents is already high and still needs to be improved in other aspects.

Table 1. Descriptive Statistics Psychological Well-Being of Respondent Based Demography

\begin{tabular}{|c|c|c|c|c|c|c|c|c|}
\hline \multicolumn{9}{|c|}{ Descriptive Statistics } \\
\hline \multirow{4}{*}{$\begin{array}{l}\text { Psychological } \\
\text { Well-Being } \\
\text { Valid N } \\
\text { (listwise) }\end{array}$} & $\mathrm{N}$ & Range & Minimum & Maximum & \multicolumn{2}{|c|}{ Mean } & Std. & Variance \\
\hline & Statistic & Statistic & Statistic & Statistic & Statistic & $\begin{array}{l}\text { Std. } \\
\text { Error }\end{array}$ & Statistic & Statistic \\
\hline & 42 & 80 & 116 & 196 & 165,26 & 3,042 & 19,716 & 388,735 \\
\hline & 42 & & & & & & & \\
\hline
\end{tabular}


Table 2. Descriptive statistics psychological well-being of respondent based on sub variables

\begin{tabular}{lccccccc}
\hline Aspek & Ideal & Max & Min & $\sum$ & Mean & \% & Sd \\
\hline Self-acceptance(8) & 40 & 39 & 16 & 1319 & 31,4 & 78,5 & 5,06 \\
Positive relations with others(6) & 30 & 30 & 13 & 977 & 23,3 & 77,5 & 3,7 \\
Autonomy (8) & 40 & 38 & 23 & 1349 & 32,1 & 80 & 3,5 \\
Purpose in life(6) & 30 & 29 & 11 & 952 & 22,7 & 75,6 & 4 \\
Personal growth(6) & 30 & 29 & 18 & 1003 & 23,9 & 79,6 & 2,7 \\
Environmental mastery(8) & 40 & 39 & 23 & 1341 & 31,9 & 79,8 & 4 \\
\hline
\end{tabular}

Frequency tables psychological well-being (PWB) of respondent based demography gender

Based on table 2 and figure 3, it can be seen that based on gender, the percentage of mean female respondents is higher than male respondents. Whereas the highest psychological well-being score often appears is male psychological well-being. This condition shows that the psychological well-being data got in this study is dominated by female respondents, but the highest psychological well-being is male.

Table 3. Frequency tables PWB of gender

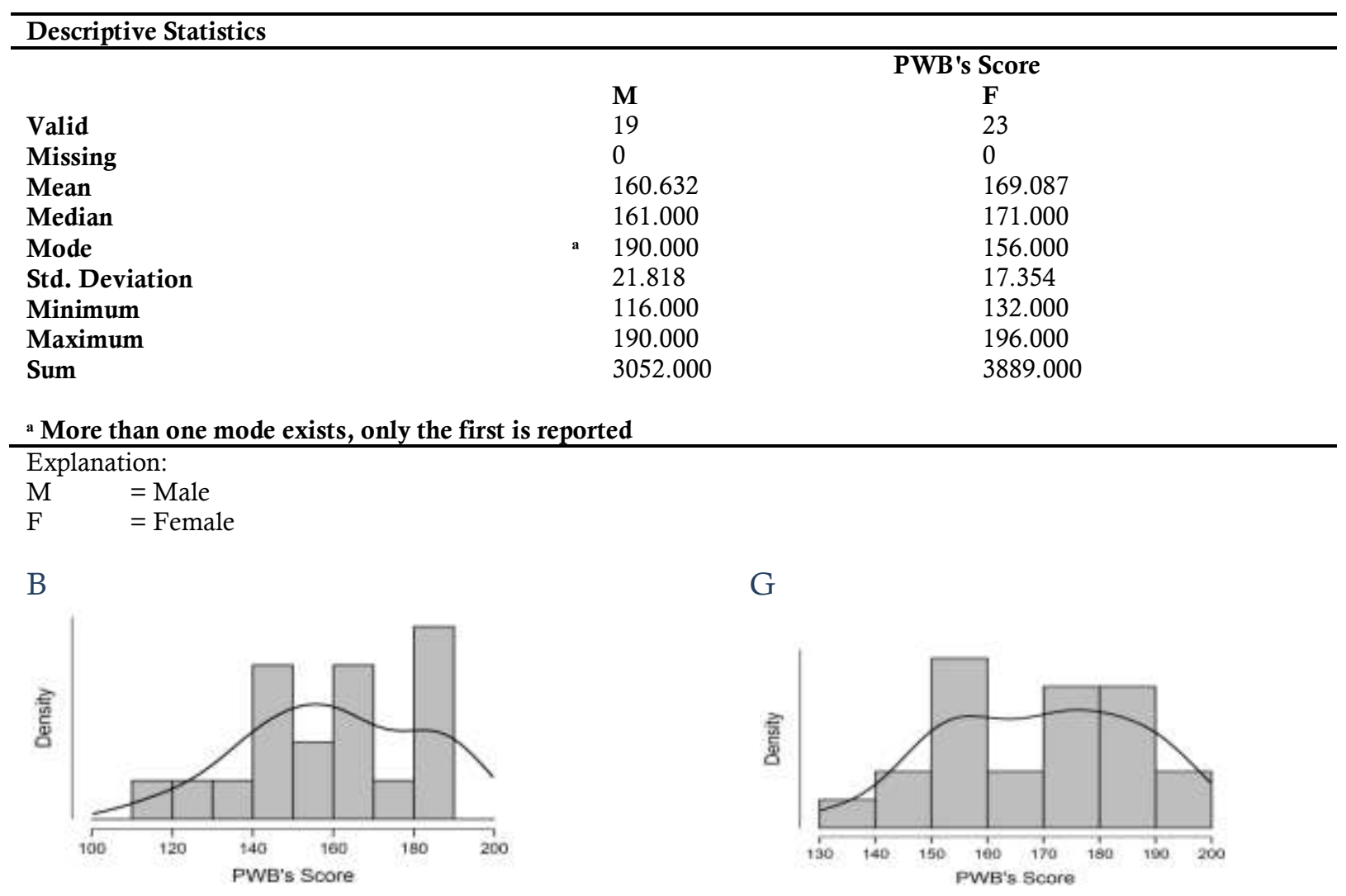

Figure 3.PWB's based on gender

\section{Ethnic}

Table 3 and Figure 4 describe that in terms of tribes, respondents came from 3 major tribes namely Minang, Batak and Javanese. Respondents who have the Minang tribe are more dominant than the Batak and Javanese tribes. The findings showed that the average psychological well-being score of respondents who came from the Minang tribe was higher than other tribes. Next, the Javanese average score and the lowest mean score are the Batak ethnic group. This finding explains that most of the research respondents were the Minang tribe. Judging from Figure 4, the psychological well-being of the dominant Batak tribe is in the medium category with a range of 140-160. Likewise, the dominant Javanese are between 140-160 
scores and on average it fills all categories. While the dominant Minang tribe has a high psychological well-being with which is between scores 180-190.

Table 4. Frequency tables PWB of ethnic

\begin{tabular}{lrrr}
\hline Descriptive Statistics & & & \\
& PWB's Score & Minang \\
Valid & Jatak & 7 & 28 \\
Missing & 7 & 0 & 0 \\
Mean & 0 & 159.143 & 169.071 \\
Median & 156.143 & 159.000 & 172.000 \\
Mode & 155.000 & 130.000 & 190.000 \\
Std. Deviation & 116.000 & 17.004 & 18.449 \\
Minimum & 25.043 & 130.000 & 132.000 \\
Maximum & 116.000 & 187.000 & 196.000 \\
Sum & 189.000 & 1114.000 & 4734.000 \\
& 1093.000 & & \\
a More than one mode exists, only the first is reported & & \\
\hline
\end{tabular}

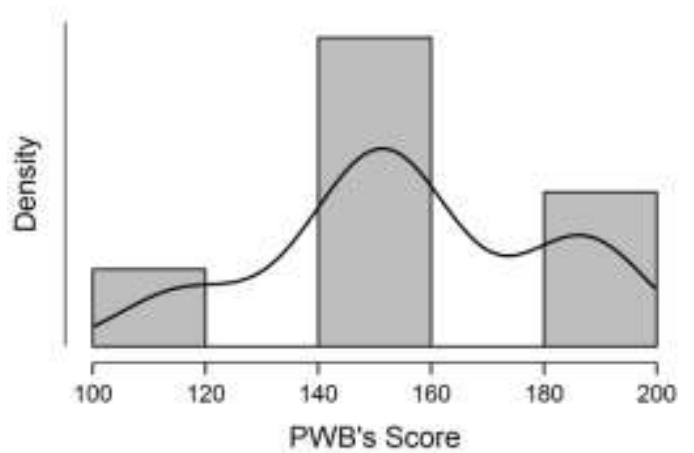

Jawa

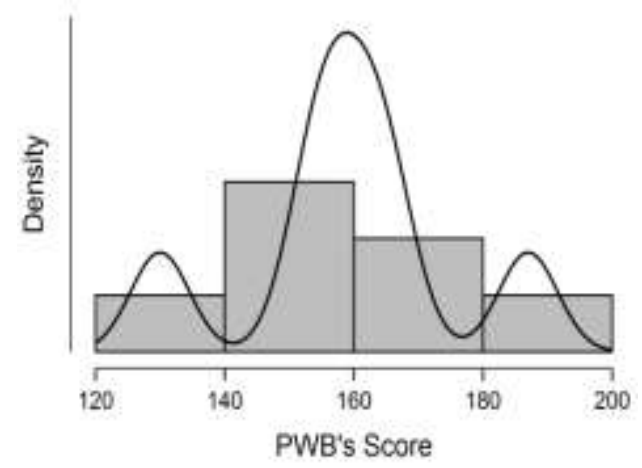

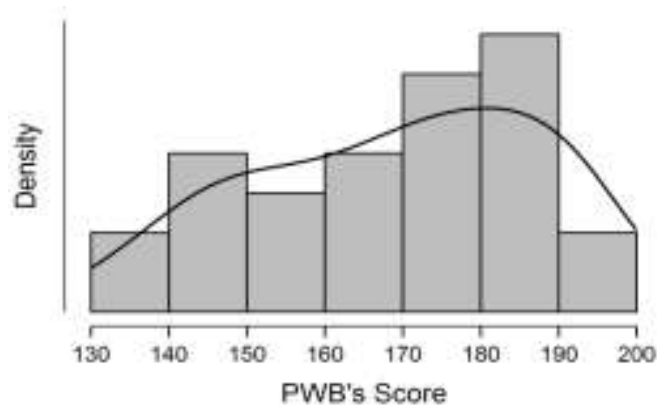

Figure 4. PWB based on ethnic

\section{Education of father}

Table 4 and figure 5 describe that in terms of parental education, shows that the education of male parents of respondents is dominated by elementary school education. The average psychological well-being score of the male parents of respondents who have the senior high school education is higher than the others. This can also be seen in the box plot + violin + jitter plot that the psychological well-being area of the male parents of respondents who have a senior high school education background is broader than the others.

Based on the graph it can be seen that the psychological well-being scores of the male parents of respondents who have an elementary school education are between 140-160. The psychological well-being scores of the respondents' male parents who had a dominant junior high school education were in the 
range 160-190. Then the psychological well-being scores of the male parents of respondents who have the senior high school education are dominant between 140-200 scores.

Table 5. Frequency tables PWB based on education of father

\begin{tabular}{lrrr}
\hline Descriptive Statistics & & & \\
\hline & PS & PWB's Score & SHS \\
Valid & & & 7 \\
Missing & 0 & 0 & 15 \\
Mean & 0 & 166.571 & 0 \\
Median & 162.750 & 170.000 & 168.000 \\
Mode & 157.500 & 132.000 & 166.000 \\
Std. Deviation & 185.000 & 18.238 & 190.000 \\
Minimum & 18.479 & 132.000 & 22.684 \\
Maximum & 130.000 & 187.000 & 116.000 \\
Sum & 190.000 & 1166.000 & 196.000 \\
& 3255.000 & & 2520.000 \\
a More than one mode exists, only the first is reported & & \\
\hline
\end{tabular}

ES

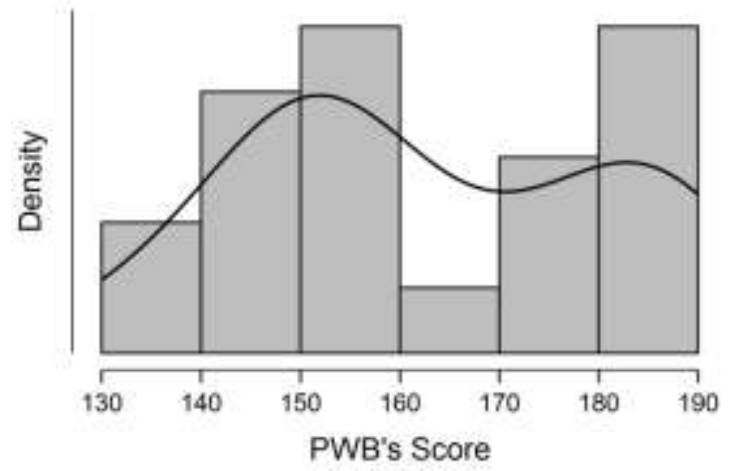

JHS

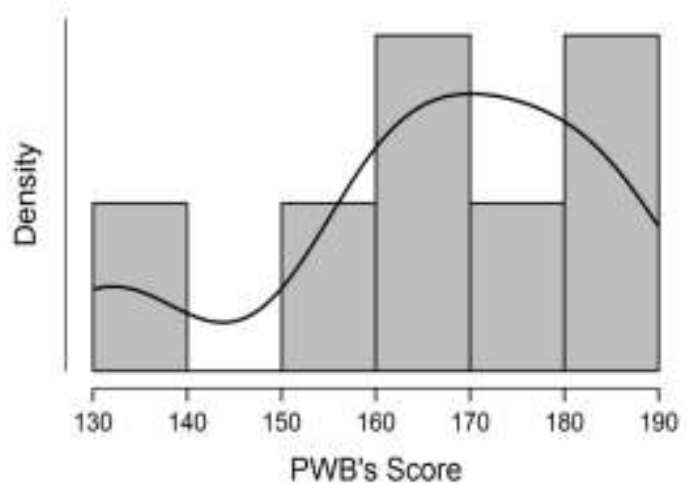

SHS

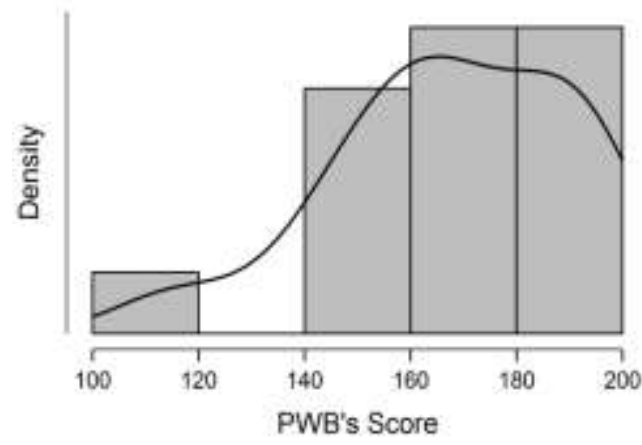

Figure 5. PWB based on education of father

Explanation:
ES = Elementary School
JHS = Junior High School
SHS = Senior High School

\section{Education of mother}

Table 5 and Figure 6 describe that in terms of parental education, shows that the education of the respondents 'parents' women is dominated by elementary school education. The average psychological well-being score of respondent female parents who have diploma education background is higher than 
other educational backgrounds, then followed by respondent female parents who have the educational background of the bachelor's degree, elementary school, senior high school and finally junior high school. Meanwhile, if viewed from the graph that the respondent's female parents who have the senior high school education background fill all categories with a range of 100-200 scores.

Table 6. Frequency tables PWB based on education of mother

\begin{tabular}{|c|c|c|c|c|c|c|}
\hline \multicolumn{7}{|c|}{ Descriptive Statistics } \\
\hline & & \multirow[b]{2}{*}{ BD } & \multicolumn{3}{|c|}{ PWB's Score } & \multirow[b]{2}{*}{ SHS } \\
\hline & & & D & ES & JHS & \\
\hline Valid & & 2 & 1 & 17 & 7 & 15 \\
\hline Missing & & 0 & 0 & 0 & 0 & 0 \\
\hline Mean & & 186.000 & 194.000 & 171.882 & 152.286 & 159.133 \\
\hline Median & & 186.000 & 194.000 & 176.000 & 156.000 & 159.000 \\
\hline Mode & a & 182.000 & 194.000 & 190.000 & 130.000 & 159.000 \\
\hline Std. Deviation & & 5.657 & $\mathrm{NaN}$ & 18.138 & 11.982 & 20.014 \\
\hline Minimum & & 182.000 & 194.000 & 138.000 & 130.000 & 116.000 \\
\hline Maximum & & 190.000 & 194.000 & 196.000 & 166.000 & 189.000 \\
\hline Sum & & 372.000 & 194.000 & 2922.000 & 1066.000 & 2387.000 \\
\hline
\end{tabular}

Figure 6. PWB based on education of mother

ES

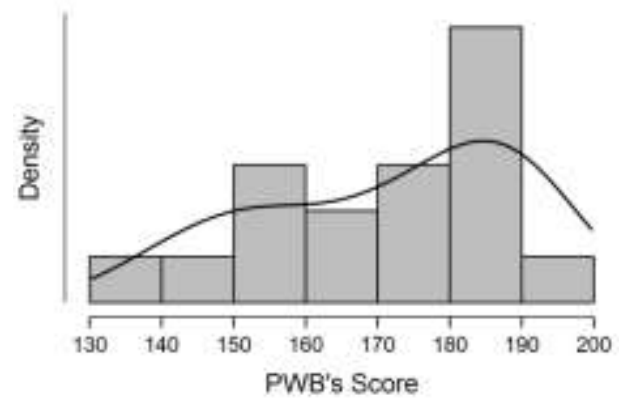

JHS

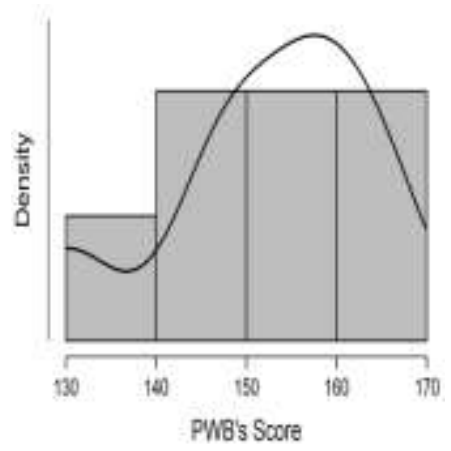

Explanation:

$$
\begin{array}{ll}
\text { ES } & =\text { Elementary School } \\
\text { JHS } & =\text { Junior High School } \\
\text { SHS } & =\text { Senior High School } \\
\text { D } & =\text { Diploma }
\end{array}
$$

\section{Comparative analysis Psychological Well-Being (PWB) of respondent based demography gender}

Based on table 7 it was found that the average PWB for women was higher than the average PWB for men. Furthermore, from the Levene's Test results, the F count is 0.715 with a probability of 0.403 . Because 
probability $>0.05$, Ho is accepted, which means that psychological well-being of men and women who live with parents of victims of domestic violence is the same.

Table 7. T-Test of Psychological Well-Being Based Gender

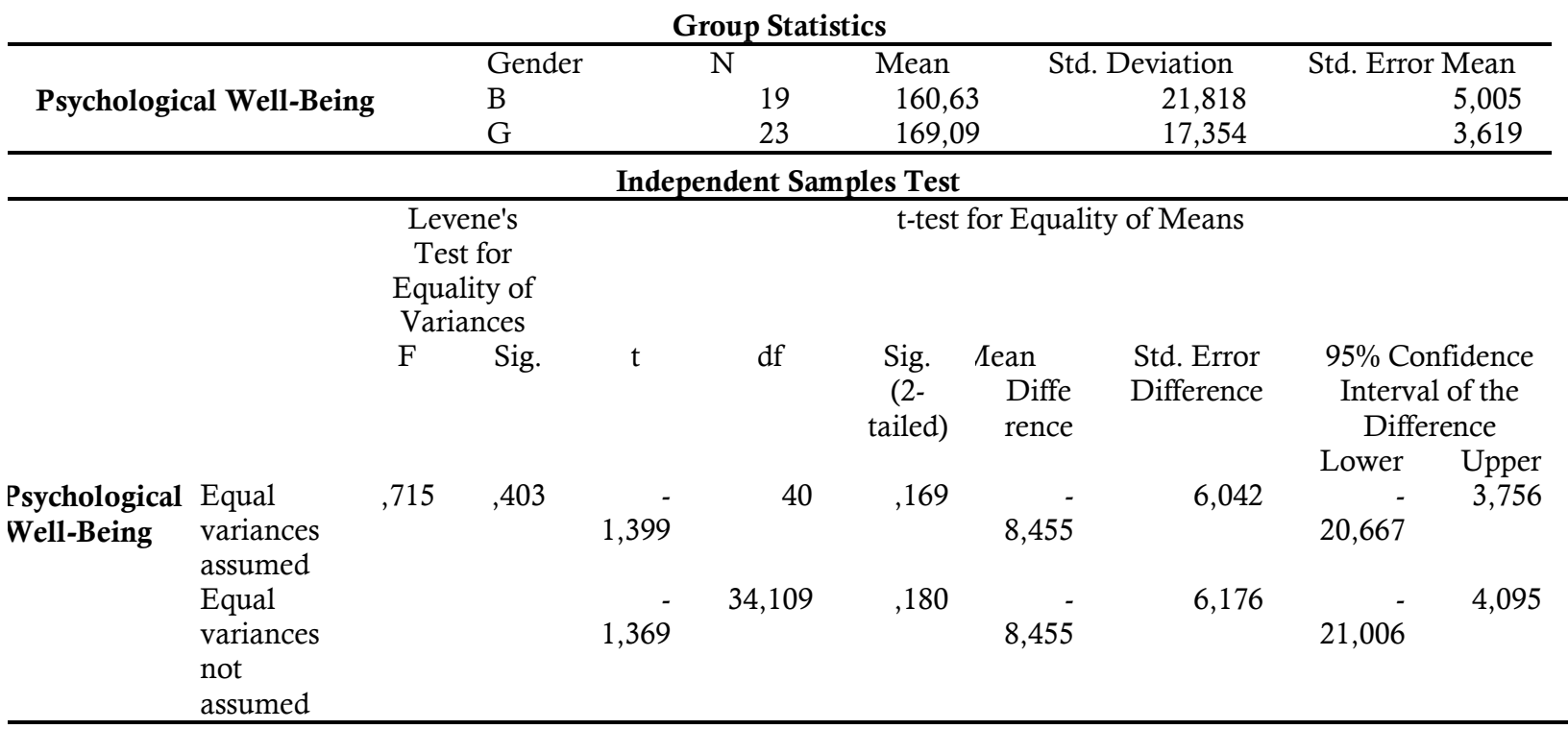

\section{Ethnic}

Based on table 8 it can be seen that the average PWB of respondents in terms of ethnicity is higher from the Minang ethnic group. The average PWB of respondents from the Minang tribe is higher than the average PWB of the Batak and Javanese tribes. Respondents from Javanese have an average PWB higher than Batak. Test results of homogeneity of variances as a prerequisite for being able to use ANOVA. The test results found that the $\mathrm{F}$ count $=0.668$ with sig $=0.518$. Because the sig value $>0.05$, it can be concluded that the variance between groups is homogeneous. Thus the prerequisites for using ANOVA are fulfilled.

Furthermore, the ANOVA table above shows the overall average difference test results. In the table found the calculated $F$ value of 1.660 with sig $=0.203$. because the sig value $>0.05$, then $\mathrm{H} 0$ is accepted so that it can be concluded that there is no significant difference in the average psychological well-being between respondents who are from Minang, Batak and Javanese ethnic groups.

Table 8. T-Test of psychological Well-Being based ethnic

\section{Descriptives}

\begin{tabular}{|c|c|c|c|c|c|c|c|c|}
\hline \multicolumn{9}{|c|}{ Psychological Well-Being } \\
\hline & $\mathrm{N}$ & Mean & Std. & \multirow{4}{*}{ Error } & \multirow{2}{*}{\multicolumn{2}{|c|}{$\begin{array}{l}\text { 95\% Confidence } \\
\text { Interval for Mean }\end{array}$}} & \multirow[t]{2}{*}{ Minimum } & Maximum \\
\hline & & & \multirow[t]{3}{*}{ Deviation } & & & & & \\
\hline & & & & & Lower & Upper & & \\
\hline & & & & & Bound & Bound & & \\
\hline Minang & 28 & 169,07 & 18,449 & 3,487 & 161,92 & 176,23 & 132 & 196 \\
\hline Batak & 7 & 156,14 & 25,043 & 9,465 & 132,98 & 179,30 & 116 & 189 \\
\hline Jawa & 7 & 159,14 & 17,004 & 6,427 & 143,42 & 174,87 & 130 & 187 \\
\hline Total & 42 & 165,26 & 19,716 & 3,042 & 159,12 & 171,41 & 116 & 196 \\
\hline \multicolumn{9}{|c|}{ 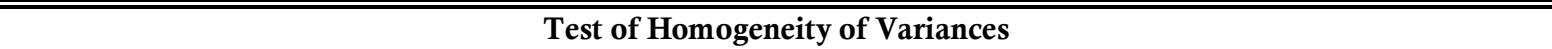 } \\
\hline \multirow{2}{*}{\multicolumn{9}{|c|}{ Psychological Well-Being }} \\
\hline & & tic & & df1 & & df2 & \multirow[b]{2}{*}{39} & \multirow[t]{2}{*}{ Sig. } \\
\hline \multicolumn{4}{|c|}{,668 } & & 2 & & & \\
\hline \multicolumn{9}{|c|}{$\overline{\text { ANOVA }}$} \\
\hline \multicolumn{3}{|c|}{ Psychological Well-Being } & $f \mathrm{C}_{\mathrm{f}}$ & $d f(f>c$ & & & & \\
\hline Between & aps & $\mathrm{Su}$ & $\begin{array}{l}\text { Squares } \\
1250,548\end{array}$ & $\mathrm{df}$ & 2 & $\begin{array}{l}\text { Square } \\
625,274\end{array}$ & ${ }_{1,660}$ & Sig. \\
\hline Within & & & 14687,571 & & 9 & 376,604 & & \\
\hline Total & & & 15938,119 & & 1 & & & \\
\hline
\end{tabular}

Journal homepage: https://jurnal.iicet.org/index.php/jppi 


\section{Education of Father (EoF)}

Based on table 9 it can be seen that the average PWB of respondents in terms of education from fathers, where the male parents of respondents who have senior high school education are higher than other educational backgrounds. The average PWB of respondents from the elementary school education background is the lowest compared to other educational backgrounds. Test results of homogeneity of variances as a prerequisite for being able to use ANOVA. The test results found that the $\mathrm{F}$ count $=0.426$ with sig $=0.656$. Because the sig value $>0.05$, it can be concluded that the variance between groups is homogeneous. Thus the prerequisites for using ANOVA are fulfilled.

Furthermore, the ANOVA table above shows the overall average difference test results. In the table found the calculated $\mathrm{F}$ value of 0.312 with sig $=0.734$. because the sig value $>0.05$ so it can be concluded that there is no significant difference in the average psychological well-being between respondents who come from elementary school, junior high school, senior high school educational backgrounds.

Table 9. T-Test of Psychological Well-Being Based Education of Father (EoF)

\begin{tabular}{|c|c|c|c|c|c|c|c|c|}
\hline \multirow{2}{*}{\multicolumn{3}{|c|}{ Psychological Well-Being }} & \multicolumn{4}{|c|}{ Descriptives } & \multirow[b]{3}{*}{ Minimum } & \multirow[b]{3}{*}{ Maximum } \\
\hline & & & & & & & & \\
\hline & \multirow[t]{3}{*}{$\mathrm{N}$} & \multirow[t]{3}{*}{ Mean } & \multirow[t]{3}{*}{$\begin{array}{c}\text { Std. } \\
\text { Deviation }\end{array}$} & \multirow[t]{3}{*}{$\begin{array}{l}\text { Std. } \\
\text { Error }\end{array}$} & \multicolumn{2}{|c|}{$\begin{array}{l}\text { 95\% Confidence Interval } \\
\text { for Mean }\end{array}$} & & \\
\hline & & & & & Lower & Upper & & \\
\hline & & & & & Bound & Bound & & \\
\hline ES & 20 & 162,75 & 18,479 & 4,132 & 154,10 & 171,40 & 130 & 190 \\
\hline JHS & 7 & 166,57 & 18,238 & 6,893 & 149,70 & 183,44 & 132 & 187 \\
\hline SHS & 15 & 168,00 & 22,684 & 5,857 & 155,44 & 180,56 & 116 & 196 \\
\hline Total & 42 & 165,26 & 19,716 & 3,042 & 159,12 & 171,41 & 116 & 196 \\
\hline \multicolumn{9}{|c|}{ "Test of Homogeneity of Variances } \\
\hline \multirow{3}{*}{\multicolumn{3}{|c|}{$\begin{array}{l}\text { Psychological Well-Being } \\
\text { Levene Statistic }\end{array}$}} & \multirow{3}{*}{\multicolumn{2}{|c|}{ df1 }} & & & \multirow{2}{*}{\multicolumn{2}{|c|}{ Sig. }} \\
\hline & & & & & & $\mathrm{df} 2$ & & \\
\hline & & & & & 2 & & 39 & 656 \\
\hline \multicolumn{9}{|c|}{ ANOVA } \\
\hline \multirow{2}{*}{\multicolumn{3}{|c|}{ Psychological Well-Being }} & & & & & & \\
\hline & & & Sum of Squares & d & & Square & F & Sig. \\
\hline $\begin{array}{l}\text { Betwec } \\
\text { Within }\end{array}$ & roup & & $\begin{array}{r}250,655 \\
15687.464\end{array}$ & & $\begin{array}{r}2 \\
39\end{array}$ & $\begin{array}{l}125,327 \\
402,243\end{array}$ & 312 & ,734 \\
\hline Total & & & 15938,119 & & 41 & & & \\
\hline
\end{tabular}

\section{Education of Mother (EoM)}

Based on table 10 it can be seen that the average PWB of respondents in terms of education from mothers, where the parents of female respondents who have diploma education is higher than other educational backgrounds. The average PWB of respondents from the junior high school education background is the lowest compared to other educational backgrounds. Test results of homogeneity of variances as a prerequisite for being able to use ANOVA. The test results found that the $\mathrm{F}$ count $=1.3366$ with sig $=$ 0.277 . Because the sig value $>0.05$, it can be concluded that the variance between groups is homogeneous. Thus the prerequisites for using ANOVA are fulfilled.

Furthermore, the ANOVA Table 10 shows the overall average difference test results. In the table found the calculated $\mathrm{F}$ value of 3281 with sig $=0.021$. because of the value of sig $<0.05$ then Ho is rejected so it can be concluded that there is a significant difference in the average psychological well-being between respondents who have female parents with educational backgrounds who come from elementary school, junior high school, senior high school, diploma, bachelor degree.

The research findings explain that psychological well-being of adolescents living with domestic violence is upward. These findings are influenced by many factors including demographics of respondents. First, based on the result, it can be described that the first is reviewed in terms of gender, Average score the psychological male well being is lower than the psychological wellbeing of women. This finding is supported by research that the low psychological-well being the score of men is because men have a tendency to have a stronger psychological impact than women (Evans, et al., 2008; Goss-Sampson, 2018). In addition, other research findings also mention a significant relationship between psychological wellbeing and gender between ages 14 to 17 and 19 to 25 years (Eryllmaz \& Ercan, 2016). Shah said that 
women have a higher psychological well-being than men. Women always try very hard to adjust to the environment, social relationships and even academic achievement, women are more timely at work. However, men are not always low (Shah, 2014). Women also tend to support psychological well-being so that women's psychological well-being is higher than men (Korkmaz, 2012; Özen \& Gülaçt1, 2012; Topuz, 2013; Y1lmaz, 2013).

Table 10. T-Test of Psychological Well-Being Based Education of Mother (EoM) Descriptives

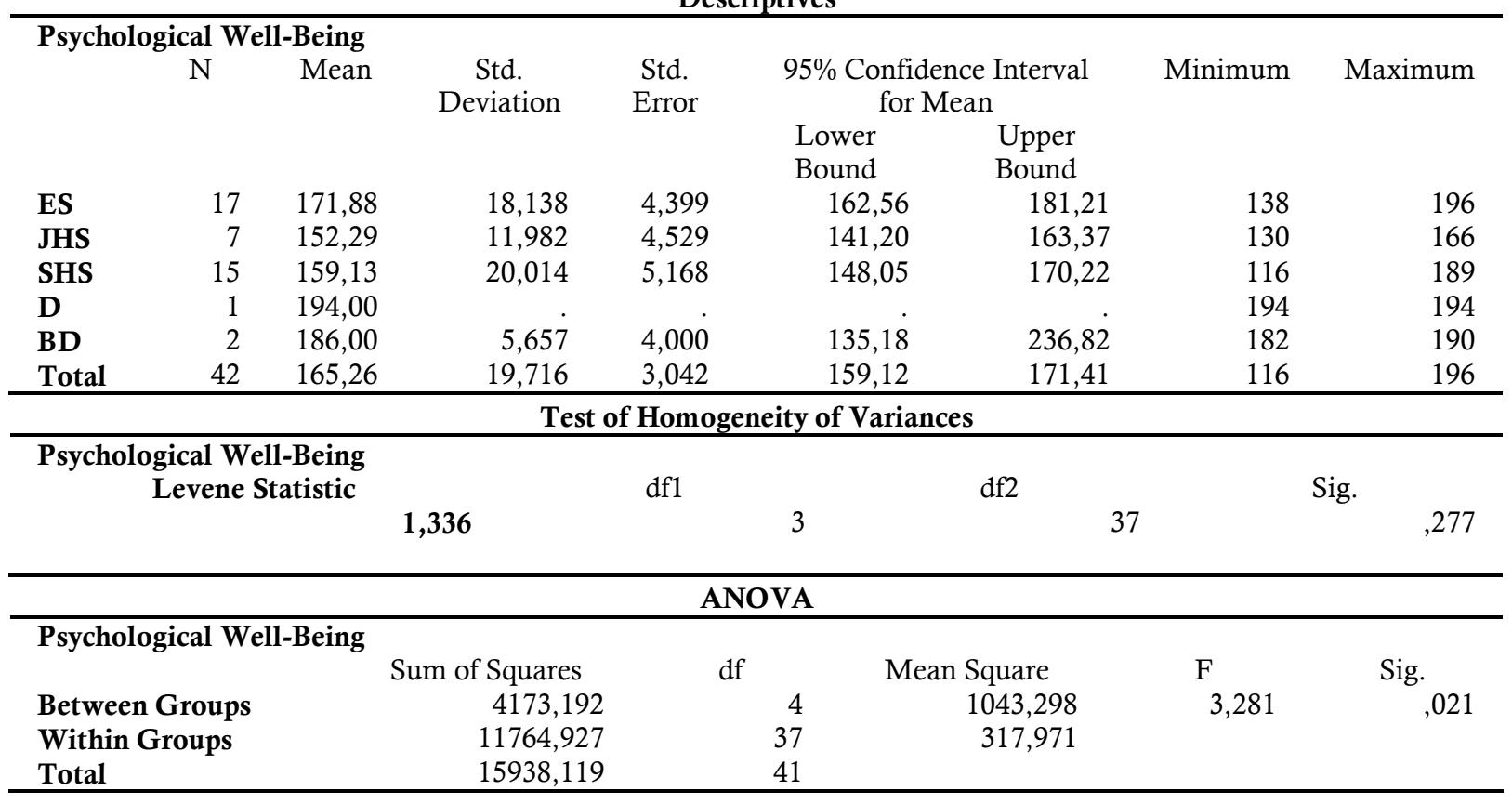

The highest psychological well-being score compared to other scores is male psychological well-being score. This means that, when viewed from the score, the psychological well-being of men is higher than women. Findings also support this finding that the level of psychological well-being of men is higher than that of women (Güven, 2008). The results of the psychological well-being t-test for male and female respondents showed no significant difference. This finding is in line with the percentage of psychological well-being conditions of adolescents living with domestic violence from the analysis per sub-variable each in a high condition. As seen in table 2 where the sub-variables of autonomy, mastery of the environment, and self-acceptance of respondents have a higher average. Individuals who have the ability of autonomy, namely self-directed and independent in regulating behavior, will do coping to help themselves overcome the problems they experience. There are also studies that find that there are no significant differences in psychological well-being students in terms of gender (Canbay, 2010; İlhan, 2005; Osmanoğlu \& Kaya, 2013; Timur, 2008; Tuzgöl Dost, 2004). This condition is supported by the finding that women report often experiencing poor psychological conditions such as feeling unhappy, depressed, and consider themselves worthless (Dahlke et al., 2018). Individuals who have high psychological well-being will accept the state of their lives, can be grateful for what is in their lives (Ghoniyah, 2015) despite having a family background of domestic violence. Based on the explanation above, it can be seen that there are various findings that support the findings of this study.

Second, in terms of the respondent's tribe from the Minang tribe, it has a high psychological well being compared to other tribes. Meanwhile, respondents from Batak ethnic groups have a low psychological well being compared to other tribes. The results showed that the psychological well-being of ethnic minorities (Batak and Javanese) was lower than the majority ethnic group namely Minang. This happened because the ethnic Batak and Javanese were in the majority ethnic environment, Minang. The results of the different psychological well-being conditions of adolescents living with parents of domestic violence victims in terms of ethnic Minang, Batak and Javanese found no significant differences. This condition if discrimination based on ethnic membership can affect the psychological well-being of ethnic minorities (Ferrari, Rosnati, Canzi, Ballerini, \& Ranieri, 2017). As for the community, there is a certain dislike of ethnic X towards certain ethnic minorities in the community (Nur, 2016; Romli, 2014). As supported by the findings that in the school environment there is a social prediction which is the dislike of students 
towards certain ethnic groups so that it does not establish good social relations (D. R. Hidayat, 2012). The origin of the respondent's ethnicity will influence the viewpoint and mindset of acceptance of domestic violence conditions that occur. This is because the tribe is inseparable from culture. The cultural values of a particular tribal society will shape the behavior and perspective of a society on certain matters, one of which is the perspective on psychological well-being. Value is a conception that can encourage and direct someone in acting, for example in working and acting (Muslihati, 2014). Other research findings also explained that psychological well-being interacted significantly with the racial/ethnic background of adolescents (Bucchianeri, et al., 2016).

Viewed in terms of culture, psychological well-being for Western culture people refers to the achievement of personal goals (personal achievement), independent, independent of which can be interpreted as the achievement of actualization (self actualization), whereas for people in Eastern culture psychologically prosperous refers to building good interpersonal and social relationships with the environment (Fava \& Ruini, 2014). This supports the findings that the dominant psychological well-being and above are also influenced by the cultural aspects of the respondents.

Culture is interpreted as the mindset and pattern of action of an individual whose essence contains the values, beliefs, agreements and portraits of harmony of a community that develops and is passed down from generation to generation (Muslihati, 2014). The cultural values of a particular ethnic community will shape the behavior and outlook of a community on certain things, one of which is the perspective on psychological well-being. Value is a conception that can encourage and direct someone to act, for example in working and acting.

It can be said that through good socio-economic status can channel various facilities able to provide happiness. Sharma gave results through his research, that groups of high-income individuals had better psychological well-being compared to groups with low income (Sharma \& Sahu, 2014). This is supported by several studies that the psychological well-being of children and adolescents is related to the socioeconomic factors of their parents (Tartakovsky, 2010). As is known that one cause of domestic violence is economic conditions, so it also affects the height and low psychological well-being of individuals.

Third, the results showed that the respondent's male parent, Father / Dad / Daddy, based on the average score found that the respondent's male parents who had senior high school education had high psychological well-being. Meanwhile, female parents namely Mother / Mom / Amak based on average scores found that the respondent female parents who had a bachelor degree educational background had higher psychological well-being compared to the others. The results of different psychological well-being conditions of adolescents who lived with the parents of victims of domestic violence in terms of father's educational background there were no significant differences. Meanwhile, respondents living with female parents were found to have significant differences in psychological well-being conditions when viewed from a mother's educational background. This finding is according to findings that state that education, in general, the higher the education of a person, the better psychological well-being, especially in the dimensions of life goals and personal development. Education is a source of psychological well-being because it can form independence and competence for individuals (Werdyaningrum, 2013). Other findings are contrary to other findings that educational background does not significantly influence psychological well-being (Vania \& Dewi, 2014). The results of other study also explain that higher education also influences psychological well-being (Amawidyati \& Utami, 2007; Papalia, Sterns, Feldman, \& Camp, 2006; Ryff, 1984; Ryff \& Singer, 2008).

Highly educated groups have higher life purpose dimensions and personal growth dimensions than those with low education. Education the higher a person's education, the better psychological being is better, especially in the dimensions of life goals and personal development. Education is one source of psychological well-being because it can form independence and competence for individuals (Werdyaningrum, 2013). This is also in line with the findings that the factors that influence the psychological well-being of adolescents living with victims of domestic violence include gender (Kumcagiz \& Gündüz, 2016), thnicity, and parental education. The implication of the psychological well-being inventory is to help school counselor in schools to provide appropriate and optimal services by considering demographic analysis from clients. In addition, it is important to establish the communication between school counselor and parents (Epstein \& Van Voorhis, 2010; Mitchell \& Bryan, 2007; Moran \& Bodenhorn, 2015) so that they can realize family and school collaboration (Juškienė \& Stasiulienè, 2019). So the services provided can help students to have a constant psychological well-being both in themselves. 


\section{Conclusions}

The findings of the study explained that psychological adolescents living with their parents experienced domestic violence from several demographic indicators. First, based on gender, the male adolescent psychological well-being score was lower than the female adolescent psychological well-being score. Second, the psychological well-being score of adolescents from the Minang tribe was higher than the psychological well-being scores of adolescents from other tribes. Third, the psychological well-being scores of adolescents with an educational background of Bachelor Degree parents were higher than adolescents with other educational backgrounds. Then, the results of the comparative test carried out on the psychological well-being of adolescents based on gender and ethnicity had no differences, but the psychological well-being of adolescents in terms of their parents' educational background had differences. Based on this, guidance and counseling services should be specifically focused for adolescents whose parents have educational backgrounds in elementary school, junior high school and senior high school and demographics such as gender and ethnicity that also need to be considered by the counselor.

\section{References}

Achmad, M. (2005). Psikologi Keluarga, dari keluarga sakinah hingga keluarga bangsa.

Afdal, A. (2015). Pemanfaatan Konseling Keluarga Eksperensial untuk Penyelesaian Kasus Kekerasan dalam Rumah Tangga. Jurnal EDUCATIO: Jurnal Pendidikan Indonesia, 1(1).

Amawidyati, S. A. G., \& Utami, M. S. (2007). Religiusitas dan psychological well-being pada korban gempa. Jurnal Psikologi, 34(2), 164-176.

Anggraeni, R. D. (2013). Dampak Kekerasan Anak Dalam Rumah Tangga. Artikel Ilmiah Hasil Penelitian Mahasiswa, 1(1).

Anjani, S. D. (2016). Penegakan hukum tindak pidana kekerasan dalam rumah tangga dengan menggunakan konsep hukum progresif (studi kasus pada Polsek Natar): Universitas Lampung.

Bell, D., \& Bennett, B. (2017). Genetic secrets and the family (pp. 209-240): Routledge.

Berzonsky, M. D., \& Cieciuch, J. (2016). Mediational role of identity commitment in relationships between identity processing style and psychological well-being. Journal of Happiness Studies, 17(1), 145162.

Bodden, D. H. M., \& Deković, M. (2016). Multiproblem families referred to youth mental health: What's in a name? Family process, 55(1), 31-47.

Borneo, J. (2016). Analisis kriminologi terhadap kekerasan dalam rumah tangga di kecamatan Pontianak Utara. Jurnal Hukum Prodi Ilmu Hukum Fakultas Hukum Untan (Jurnal Mahasiswa S1 Fakultas Hukum) Universitas Tanjungpura, 4(3).

Bosch, J., Weaver, T. L., Arnold, L. D., \& Clark, E. M. (2017). The impact of intimate partner violence on women's physical health: Findings from the Missouri behavioral risk factor surveillance system. Journal of interpersonal violence, 32(22), 3402-3419.

Brian, M. (2015). Dawn of Australian Domestic Violance. Eureka Street, 25(24).

Bucchianeri, M. M., Fernandes, N., Loth, K., Hannan, P. J., Eisenberg, M. E., \& Neumark-Sztainer, D. (2016). Body dissatisfaction: Do associations with disordered eating and psychological well-being differ across race/ethnicity in adolescent female and male? Cultural Diversity and Ethnic Minority Psychology, 22(1), 137-137.

Callahan, M. R., Tolman, R. M., \& Saunders, D. G. (2003). Adolescent dating violence victimization and psychological well-being. Journal of adolescent research, 18(6), 664-681.

Canbay, H. (2010): DEÜ Eğitim Bilimleri Enstitüsü.

Carter, I. (2017). Human behavior in the social environment: A social systems approach: Routledge.

Dahlke, A. R., Johnson, J. K., Greenberg, C. C., Love, R., Kreutzer, L., Hewitt, D. B., . . Bilimoria, K. Y. (2018). Gender Differences in Utilization of Duty-hour Regulations, Aspects of Burnout, and Psychological Well-being Among General Surgery Residents in the United States. Annals of Surgery, 268(2).

Dibble, U., \& Straus, M. A. (2017). Some social structure determinants of inconsistency between attitudes and behavior: The case of family violence (pp. 167-180): Routledge.

Epstein, J. L., \& Van Voorhis, F. L. (2010). School counselors' roles in developing partnerships with families and communities for student success. Professional School Counseling, 14(1), 2156759X1001400102-1002156759X1001400102. 
Eryılmaz, A., \& Ercan, L. (2016). Öznel iyi oluşun cinsiyet, yaş grupları ve kişilik özellikleri açısından incelenmesi. Türk Psikolojik Danışma ve Rehberlik Dergisi, 4(36).

Evans, S. E., Davies, C., \& DiLillo, D. (2008). Exposure to domestic violence: A meta-analysis of child and adolescent outcomes. Aggression and violent behavior, 13(2), 131-140.

Fava, G. A., \& Ruini, C. (2014). Increasing psychological well-being in clinical and educational settings. Interventions and Cultural Contexts. Cross-Cultural Advancements in Positive Psychology, 8.

Ferrari, L., Rosnati, R., Canzi, E., Ballerini, A., \& Ranieri, S. (2017). How international transracial adoptees and immigrants cope with discrimination? The moderating role of ethnic identity in the relation between perceived discrimination and psychological well-being. Journal of Community \& Applied Social Psychology, 27(6), 437-449.

Foshee, V. A., Reyes, H. L. M., Chen, M. S., Ennett, S. T., Basile, K. C., DeGue, S., . . Bowling, J. M. (2016). Shared risk factors for the perpetration of physical dating violence, bullying, and sexual harassment among adolescents exposed to domestic violence. Journal of youth and adolescence, 45(4), 672-686.

Ghoniyah, Z. (2015). Gambaran psychological well being pada perempuan yang memiliki anak down syndrome. Character: Jurnal Penelitian Psikologi., 3(3).

Goss-Sampson, M. A. (2018). Statistical analysis in JASP: A guide for students. Retrieved from.

Güven, H. (2008). Depresyon ve dindarlık ilişkisi. Yayınlanmamış Yüksek Lisans Tezi. istanbul: Marmara Üniversitesi SBE.

Hidalgo, J. T., Bravo, B. N., Martínez, I. P., Pretel, F. A., Postigo, J. M., \& Rabadán, F. E. (2010). Psychological well-being, assessment tools and related factors. IE Wells, Psychological well being, 77113.

Hidayat, A. A. A. (2007). Siapa bilang anak sehat pasti cerdas: Elex Media Komputindo.

Hidayat, D. R. (2012). Faktor-Faktor Penyebab Kemunculan Prasangka Sosial (Social Prejudice) pada Pelajar. INSIGHT: Jurnal Bimbingan Konseling, 1(1), 41-48.

Hughes, C., Bolis, M., Fries, R., \& Finigan, S. (2015). Women's economic inequality and domestic violence: exploring the links and empowering women. Gender \& Development, 23(2), 279-297.

ilhan, T. (2005). Öznel iyi oluşa dayalı mizah tarzları modeli. Yayımlanmamış yüksek lisans tezi, Gazi Üniversitesi, Ankara, Türkiye.

Jonsson, L. S., Bladh, M., Priebe, G., \& Svedin, C. G. (2015). Online sexual behaviours among Swedish youth: associations to background factors, behaviours and abuse. European child \& adolescent psychiatry, 24(10), 1245-1260.

Juškienè, V., \& Stasiulienè, V. (2019). The Model of a School and Family Communication. Pedagogika, 133(1), 227-247. doi: 10.15823/p.2019.133.13

Kathryn, G., \& David, G. (2011). Konseling Keluarga. Yogyakarta: Pustaka Pelajar.

Katz, E. (2016). Beyond the physical incident model: How children living with domestic violence are harmed by and resist regimes of coercive control. Child Abuse Review, 25(1), 46-59.

Kidman, R., \& Palermo, T. (2016). The relationship between parental presence and child sexual violence: evidence from thirteen countries in sub-Saharan Africa. Child abuse \& neglect, 51, 172-180.

Korkmaz, N. E. (2012). Tanri'ya Bağlanma Ve Psikolojik İyi Olma.

Kumcagiz, H., \& Gündüz, Y. (2016). Relationship between Psychological Well-Being and Smartphone Addiction of University Students. International Journal of Higher Education, 5(4), 144-156.

Lansford, J. E., Godwin, J., Tirado, L. M. U., Zelli, A., Al-Hassan, S. M., Bacchini, D., . . . DeaterDeckard, K. (2015). Individual, family, and culture level contributions to child physical abuse and neglect: A longitudinal study in nine countries. Development and psychopathology, 27(4pt2), 1417-1428.

Levendosky, A. A., Huth-Bocks, A. C., Shapiro, D. L., \& Semel, M. A. (2003). The impact of domestic violence on the maternal-child relationship and preschool-age children's functioning. Journal of family psychology, 17(3), 275-275.

Lian, T. C., \& Yusooff, F. (2009). The effects of family functioning on self-esteem of children. European Journal of Social Sciences, 9(4), 643-650.

López-Torres Hidalgo, J., Bravo, B. N., Martínez, I. P., Pretel, F. A., Postigo, J. M. L., \& Rabadán, F. E. (2010). Psychological Well-Being, Assessment Tools and Related Factors. Psychological Well-Being (edited by Ingrid E. Wells). Hauppauge: Nova Science Publishers, 77-113.

Maguire-Jack, K., \& Showalter, K. (2016). The protective effect of neighborhood social cohesion in child abuse and neglect. Child abuse \& neglect, 52, 29-37.

Mardiyati, I. (2015). Dampak Trauma Kekerasan Dalam Rumah Tangga Terhadap Perkembangan Psikis Anak. Raheema, 2(1). 
Margaretha, N., \& Rachim, R. (2013). Trauma Kekerasan Masa Kanak Dan Kekerasan Dalam Relasi Intim. Jurnal Makara Seri Sosial Humaniora, 17(1), 33-42.

Merung, P. V. (2016). Kajian Kriminologi Terhadap Upaya Penanganan Kasus Kekerasan Dalam Rumah Tangga (KDRT) Di Indonesia. Veritas et Justitia, 2(2), 397-423.

Minkus, T., Liu, K., \& Ross, K. W. (2015). Children seen but not heard: When parents compromise children's online privacy.

Misero, P. S., \& Hawadi, L. F. (2012). Adjustment Problems dan Psychological Well-Being pada Siswa Akseleran (Studi Korelasional pada SMPN 19 Jakarta dan SMP Labschool Kebayoran Baru). Jurnal Psikologi Pitutur, 1(1).

Mitchell, N. A., \& Bryan, J. A. (2007). School-family-community partnerships: Strategies for school counselors working with Caribbean immigrant families. Professional School Counseling, 10(4), 2156759X0701000413-0702156759X0701000413.

Moran, K., \& Bodenhorn, N. (2015). Elementary School Counselors' Collaboration with Community Mental Health Providers. Journal of School Counseling, 13(4), n4-n4.

Muslihati, N. T. (2014). Nilai-nilai Psychological Well-Being dalam Budaya Madura dan Kontribusinya pada Pengembangan Kesiapan Karier Remaja Menghadapi Bonus Demografi. Jurnal Studi Sosial, 2, 120-125.

Nayana, F. N. (2013). Kefungsian keluarga dan subjective well-being pada remaja. Jurnal Ilmiah Psikologi Terapan, 1(2), 230-244.

Niolon, P. H., Vivolo-Kantor, A. M., Latzman, N. E., Valle, L. A., Kuoh, H., Burton, T., . . Tharp, A. T. (2015). Prevalence of teen dating violence and co-occurring risk factors among middle school youth in high-risk urban communities. Journal of Adolescent Health, 56(2), S5-S13.

Nur, R. (2016). Konservasi Kearifan Budaya Lokal dalam Proses Interaksi Sosial Etnis Melayu di Kabupaten Batu Bara. ISLAMICA: Jurnal Studi Keislaman, 10(2), 325-348.

Osmanoğlu, D. E., \& Kaya, H. i. (2013). Öğretmen Adaylarinin Yükseköğretime Dair Memnuniyet Durumlari ile Öznel lyi Oluş Durumlarinin Değerlendirilmesi: Kafkas Üniversitesi Örneği. Kafkas Universitesi. Sosyal Bilimler Enstitu(12), 45-70.

Özen, Y., \& Gülaçtı, F. (2012). Öğretmen adaylarının sosyal beceri ve psikolojik iyi oluş düzeylerinin incelenmesi. Uluslararası Hakemli Beşeri ve Akademik Bilimler Dergisi, 1(1), 83-101.

Papalia, D. E., Sterns, H., Feldman, R. D., \& Camp, C. (2006). Adult development and aging: McGraw-Hill Humanities/Social Sciences/Languages.

Pattiradjawane, C., Wijono, S., \& Engel, J. D. (2019). Uncovering Violence Occurring in Dating Relationsip: An Early Study Of Forgiveness Approach. PSIKODIMENSIA, 18(1), 9-18.

Perkins, C., Wood, L., Varjas, K., \& Vanegas, G. (2016). Psychological well-being of children and youth in Mexico (pp. 115-135): Springer.

Pinto, S., Fumincelli, L., Mazzo, A., Caldeira, S., \& Martins, J. C. (2017). Comfort, well-being and quality of life: Discussion of the differences and similarities among the concepts. Porto Biomedical Journal, 2(1), 6-12.

Prihantini, A. (2018): Universitas Islam Indonesia.

Rivas, C., Ramsay, J., Sadowski, L., Davidson, L. L., Dunnes, D., Eldridge, S., . . . Feder, G. (2016). Advocacy Interventions to Reduce or Eliminate Violence and Promote the Physical and Psychosocial Well-Being of Women who Experience Intimate Partner Abuse: A Systematic Review. Campbell Systematic Reviews, 12(1), 1-202.

Romli, K. (2014). Prasangka Sosial dalam Komunikasi Antaretnis (studi Antara Suku Bali dengan Suku Lampung di Kecamatan Sidomulyo Kabupaten Lampung Selatan Provinsi Lampung). KOM \& REALITAS SOSIAL, 4(2).

Rusyidi, B., \& Raharjo, S. T. (2018). Peran pekerja sosial dalam penanganan kekerasan terhadap perempuan dan anak. Sosio Informa, 4(1).

Ryff, C. D. (1984). Personality development from the inside: The subjective experience of change in adulthood and aging. Life-span development and behavior, 6, 243-279.

Ryff, C. D., \& Singer, B. H. (2008). Know thyself and become what you are: A eudaimonic approach to psychological well-being. Journal of happiness studies, 9(1), 13-39.

Sanders, C. K. (2015). Economic abuse in the lives of women abused by an intimate partner: A qualitative study. Violence against women, 21(1), 3-29.

Shah, N. (2014). A comparative study of psychological-well-being among female and male. Indian Journal of Health and Wellbeing, 5(8), 976-976. 
Sharma, S. S., \& Sahu, K. (2014). A study of psychological well-being of rural and urban young adults belonging to high income group and middle income group. Indian Journal of Health and Wellbeing, 5(12), 1508-1508.

Stanko, E. A. (2017). Theorizing about violence: Observations from the Economic and Social Research Council's violence research program (pp. 113-125): Routledge.

Straus, M. (2017). Physical violence in American families: Routledge.

Sutherland, M. A., Fantasia, H. C., \& Hutchinson, M. K. (2016). Screening for intimate partner and sexual violence in college women: Missed opportunities. Women's health issues, 26(2), 217-224.

Tartakovsky, E. (2010). The psychological well-being of russian and ukrainian adolescents in the postperestroika period: the effects of the macro-and micro-level systems. $i i, 135-135$.

Timur, M. S. (2008). Boşanma sürecinde olan ve olmayan evli bireylerin psikolojik iyi oluş düzeylerini etkileyen faktörlerin incelenmesi. Yayınlanmamış Yüksek Lisans Tezi, Ankara Universitesi Eğitim Bilimleri Enstitüsü, Ankara.

Topuz, C. (2013). Üniversite öğrencilerinde özgeciliğin öznel iyi oluş ve psikolojik iyi oluş ile ilişkisinin incelenmesi. Yayınlanmamış yüksek lisans tezi, Fatih Üniversitesi Sosyal Bilimler Enstitüsü, istanbul.

Tuzgöl Dost, M. (2004). Üniversite öğrencilerinin öznel iyi oluş düzeyleri. Yayımlanmamış Yüksek Lisans Tezi, Hacettepe Üniversitesi, Ankara.

Unicef. (2006). Behind closed doors: The impact of domestic violence on children: Unicef.

Vania, I. W., \& Dewi, K. S. (2014). Hubungan Antara Dukungan Sosial dengan Psychological Well-Being Caregiver Penderita Gangguan Skizofrenia. Empati, 3(4), 266-278.

Victor, B. G., Grogan-Kaylor, A., Ryan, J. P., Perron, B. E., \& Gilbert, T. T. (2018). Domestic violence, parental substance misuse and the decision to substantiate child maltreatment. Child abuse \& neglect, $79,31-41$.

Werdyaningrum, P. (2013). Psychological well-being pada remaja yang orang tua bercerai dan yang tidak bercerai (utuh). Jurnal Online Psikologi, 1(2).

Willis, S. S. (2009). Konseling Keluarga (Family Counseling). Bandung: Alfabeta.

Winstok, Z., \& Sowan-Basheer, W. (2015). Does psychological violence contribute to partner violence research? A historical, conceptual and critical review. Aggression and Violent Behavior, 21, 5-16.

Yi, C.-C. (2012). Introduction to the psychological well-being of East Asian youth: the transition from early adolescence to young adulthood (pp. 1-26): Springer.

Y1lmaz, M. F. (2013): Anadolu Üniversitesi.

Zembe, Y. Z., Townsend, L., Thorson, A., Silberschmidt, M., \& Ekstrom, A. M. (2015). Intimate partner violence, relationship power inequity and the role of sexual and social risk factors in the production of violence among young women who have multiple sexual partners in a peri-urban setting in South Africa. PLoS One, 10(11), e0139430-e0139430. 